\title{
Seasonal Abundance of Waterfowls, Belongs to Various Ecological Groups in Muriyad Kole Wetland, Thrissur, Kerala
}

\author{
Ajitha K. V. ${ }^{1}$, Boby Jose ${ }^{2}$ \\ PG and Research Department of Zoology, St. Joseph's College, Devagiri, University of Calicut, Kerala, India
}

\begin{abstract}
The study was focused on the waterfowl communities which belong to various ecological groups of the Muriyad kole wetland situated in the Thrissur District during the period 2010-2014 .They are ecologically grouped into five categories, on the basis of their activities seen in the kole such as divers, swimmers, small waders, large waders and aerial foragers. The small waders were the most dominant group with 18 species and followed by large waders with 16 species. The group swimmers and divers consist of 11 and 5 species respectively. The least number of species were seen in aerial foragers with 2 species. The most abundant group belongs to the various eco. group as follows; Microcarbo niger among divers, Dendrocygna javanica among swimmers, Tringa glareola among small waders, Ardea intermedia among large waders and Chlidonias hybrid among aerial foragers.Diversity in the Kole habitat promotes high species diversity in the area. Moreover species richness is high in the pre summer season due to the dewatering stage, prior to the cultivation which promotes high prey availability from the open mudflats and these attracts a lot of migratory waterfowls.
\end{abstract}

Keywords: Divers, Swimmers, Small Waders, Large Waders, Aerial Foragers

\section{Introduction}

The Kole lands of Thrissur are the part of one of the major wetland systems on the south -west coast of India, namely Vembanad-Kole. Moreover the Kole wetlands are assigned as Ramsar Site since 2002 [16], Important Bird Area since 2004 [15] and a High Value Biodiversity Area since 2009 [17].The name Kole designates a peculiar type of cultivation practice which carried out on these lands from December to April. Kole is Malayalam word which always correlated to a luck factor, literarly means a bumper yield or high returns if the floods did not damage the crop. [8]. The habitat diversity promotes species diversity [19]. The large extent of the Kole has many different habitats such as deep water, shallow water, open mudflats, grassland and paddy fields. Birds belongs to different ecological groups were make use of these areas of Kole as a source of drinking water, for breeding, resting, shelter and social interactions which was also reported by previous workers [18].

\section{Literature Review}

Avifaunal studies of Kole wetlands were initiated in the early 1980 s. Some recent avifaunal studies reported from the Thrissur kole $[1,5,6,7 \& 22]$. AWC survey is being conducted every year in the month of January, during the peak occurrence of bird fauna.The other major studies on kole wetland ecology and aquatic biodiversity includes potentiality of the wetland for rice cultivation [8], Impacts of developmental intervention on the ecology and fish diversity of Muriyad wetland Thrissur [12], Ecological Changes and Human Consequences [12] and A multiple use of kole wetland ecosystem in Kerala [21].

\section{Study Area}

The Muriyad wetland is situated $8 \mathrm{~km}$ northeast of Irinjalakuda town, in Thrissur. The total field area is about
1,215 ha and lies between $10^{\circ} 25^{\text {ee }} 32^{\text {eee }}, 10^{\circ} 18^{\text {ee }} 47^{\text {eee }} \mathrm{N}$ latitude $76^{\circ} 17^{\text {ec }} 19^{\prime \prime}, 76^{\circ} 12^{\text {ce }} 48^{\prime \prime}$ "E. longitude [12] .The geographical distribution of this area coming under Muriyad, Porathissery, Velukkara,Parappukkara Panchayats, and part of Irinjalakkuda Municipality.

\section{Materials and Methods}

The study aimed at the estimation of the waterfowl communities belongs to various ecological groups of the Muriyad Kole wetland situated in the Thrissur District. The study mainly concentrated in the selected area Thommana Kole one of the major part of Muriyad Kole wetland. Sampling was done on the basis of AWC data sheet, only waterfowls were included in the study. Line transect method was used for counting birds in this study. In this method the observer walks along a predetermined straight line and records the birds, which he sees or hears. By the line transect method the relative frequency of different species of birds and the relative frequency of the same species in different habitats can be calculated. However this is a relative method and the densities obtained are underestimates [11] .As the observer was participating alone in the census, there has fifty percent probability of missing an individual bird. Thus the efficiency of this method is fifty percent. The transect was predetermined, extending a length of $2.5 \mathrm{~km}$. The width of the sampling area was fixed as $200 \mathrm{~m}$ (100 each on either side). The birds that are flying above $40 \mathrm{~m}$ height are not recorded. The counting was done during the time of $06.00 \mathrm{hrs}$ and $10.00 \mathrm{hrs}$ in the morning .A minimum of two visits were conducted every month during the period 2010-2014. The major objectives of the study are as following.

- Preparation and analysis of list of the waterfowl community belongs to various ecological groups,

- Occurrence and abundance

- Diversity and seasonality

\section{Volume 4 Issue 12, December 2015}




\section{International Journal of Science and Research (IJSR) \\ ISSN (Online): 2319-7064 \\ Index Copernicus Value (2013): 6.14 | Impact Factor (2014): 5.611}

For convenience in the study the months were categorized into four, namely

- Pre summer (December,January,February)

- Summer (March,April,May)

- Monsoon (June,July,August)

- Post Monsoon (September,October,November)

Common names and classification were followed after [9]. Normality of collected data was tested using Jarque-Bera test [10].Since all the data are normally distributed, parametric statistics, One way Anova F was used to test the significant levels of variation in abundance. Differences with a $\mathrm{p}$-value $<0.05$ was compared using Paired t- Test.

\section{Result}

\subsection{Abundance of ecological groups}

The waterfowls of Muriyad Kole wetland were ecologically grouped into five categories, on the basis of their activities seen in the Kole such as divers, swimmers, small waders, large waders and aerial foragers (Table 1). The small waders were the most dominant group with 18 species and followed by large waders with 16 species The group swimmers and divers consist of 11 and 5 species respectively. The least number of species were seen in aerial foragers with 2 species .In the total abundance of waterfowls, observed pattern of abundance is as follows; large waders $(33.53 \%)>$ swimmers $(31.37 \%)>$ small waders $(17.35 \%)>$ aerial foragers $(11.16 \%)>$ divers $(6.59 \%)$.

The common divers found in the Kole are Tachybaptus ruficollis, Microcarbo niger, Phalacrocorax fuscicollis, Anhinga melanogaster and Fulica atra. A total of 7201 divers were recorded, among these the foremost abundant diver is Microcarbo niger (87.04\%). Other divers found are the following; Tachybaptus ruficollis(6.79\%) Anhinga melanogaster(3.19\%) Fulica atra (1.90), Phalacrocorax fuscicollis $(1.07 \%)$.

Among the 34307 swimmers reported, the maximum abundance was showed by Dendrocygna javanica $(51.80 \%)$. This particular species show more than $50 \%$ of the total abundance of swimmers. Whereas the species like Nettapus coromandelianus $>$ Porphyrio porphyrio $>$ Spatula querquedula $>$ Anas poecilorhyncha $>$ Amaurornis phoenicurus, these altogether consume $48.06 \%$ of the total abundance of swimmers. Few of them showed less than $1 \%$ of abundance and they are Zapornia fusca, Gallinula chloropus, Pelecanus philippensis, Rallina eurizonoides and Gallicrex cinerea.

Out of the total 18972 small waders, the pattern of abundance was seen as Tringa glareola $(40.10 \%)>$ Charadrius dubius(23.96\%)> Glareola lacteal (15.69\%).The small waders like Metopidius indicus, Actitis hypoleucos, Vanellus indicus, Charadrius mongolus, Pluvialis fulva, Tringa stagnatilis showed less than $10 \%$ of abundance. Tringa ochropus, Charadrius alexandrines, Hydrophasianus chirurgus, Himantopus himantopu, Gallinago stenura,
Rostratula benghalensis, Calidris minuta, Tringa nebularia and Vanellus cinereus showed less than $1 \%$ of abundance.

Among the 36668 large waders group in the Kole, the most abundant were Ardea intermedia (37.77\%), Egretta egretta(32.33\%), Ardeola grayii(11.48\%) and Bubulcus ibis $(9.83 \%)$.Three large wader group were recorded less than $5 \%$ of abundance. Eleven were reported less than $1 \%$ of abundance and they are Plegadis falcinellus, Ardea purpurea, Ixobrychus flavicollis, Nycticorax nycticorax, Ardea cinerea, Ciconia episcopus, Ixobrychus cinnamomeus, Mycteria leucocephala, and Platalea leucorodia.

Chlidonias hybrida and Sterna aurantia were the two aerial foragers reported, Of these Chlidonias hybrida showed $(99.93 \%)$ of abundance.Only $(0.07 \%)$ showed by Sterna aurantia. A total of 12198 aerial foragers were recorded.

Table 1: Waterfowls included in various ecologicalgroups

\begin{tabular}{|c|c|c|}
\hline Sl. No & Bird species & Ecological groups \\
\hline 1 & Tachybaptus ruficollis & Diver \\
\hline 2 & Microcarbo niger & Diver \\
\hline 3 & Phalacrocorax fuscicollis & Diver \\
\hline 4 & Anhinga melanogaster & Diver \\
\hline 5 & Fulica atra & Diver \\
\hline 6 & Pelecanus philippensis & Swimmer \\
\hline 7 & Dendrocygna javanica & Swimmer \\
\hline 8 & Nettapus coromandelianus & Swimmer \\
\hline 9 & Spatula querquedula & Swimmer \\
\hline 10 & Anas poecilorhyncha & Swimmer \\
\hline 11 & Amaurornis phoenicurus & Swimmer \\
\hline 12 & Gallicrex cinerea & Swimmer \\
\hline 13 & Porphyrio porphyrio & Swimmer \\
\hline 14 & Gallinula chloropus, & Swimmer \\
\hline 15 & Zapornia fusca & Swimmer \\
\hline 16 & Rallina eurizonoides & Swimmer \\
\hline 17 & Metopidius indicus & Small wader \\
\hline 18 & Hydrophasianus chirurgus & Small wader \\
\hline 19 & Vanellus indicus & Small wader \\
\hline 20 & Vanellus cinereus & Small wader \\
\hline 21 & Charadrius dubius & Small wader \\
\hline 22 & Charadrius alexandrinus & Small wader \\
\hline 23 & Pluvialis fulva & Small wader \\
\hline 24 & Charadrius mongolus & Small wader \\
\hline 25 & Actitis hypoleucos & Small wader \\
\hline 26 & Tringa stagnatilis & Small wader \\
\hline 27 & Tringa ochropus & Small wader \\
\hline 28 & Tringa glareola & Small wader \\
\hline 29 & Tringa nebularia & Small wader \\
\hline 30 & Rostratula benghalensis & Small wader \\
\hline 31 & Gallinago stenura & Small wader \\
\hline 32 & Calidris minuta & Small wader \\
\hline 33 & Glareola lactea & Small wader \\
\hline 34 & Himantopus himantopu & Small wader \\
\hline 35 & Ardea cinerea & Large wader \\
\hline 36 & Ardea purpurea & Large wader \\
\hline 37 & Ardeola grayii & Large wader \\
\hline 38 & Nycticorax nycticorax & Large wader \\
\hline 39 & Ardea alba & Large wader \\
\hline 40 & Ardea intermedia & Large wader \\
\hline 41 & Egretta egretta & Large wader \\
\hline 42 & Bubulcus ibis & Large wader \\
\hline 43 & Ixobrychus cinnamomeus & Large wader \\
\hline 44 & Ixobrychus flavicollis & Large wader \\
\hline 45 & Threskiornis & Large wader \\
\hline
\end{tabular}




\section{International Journal of Science and Research (IJSR) \\ ISSN (Online): 2319-7064}

Index Copernicus Value (2013): 6.14 | Impact Factor (2014): 5.611

\begin{tabular}{|c|c|c|}
\hline 46 & Plegadis falcinellus & Large wader \\
\hline 47 & Mycteria leucocephala & Large wader \\
\hline 48 & Anastomus oscitans & Large wader \\
\hline 49 & Ciconia episcopus & Large wader \\
\hline 50 & Platalea leucorodia. & Large wader \\
\hline 51 & Sterna aurantia & Aerial Foragers \\
\hline 52 & Chlidonias hybrida & Aerial Foragers \\
\hline
\end{tabular}

\subsection{Seasonal abundance}

In pre summer Aerial Foragers are the largest group found $(47.2 \%)$, followed by swimmers $(18.8 \%)$, Large Waders (14.1\%) and Divers (11.6\%) small waders (8.2\%). In summer the abundance of, Aerial Foragers are $(29.9 \%)$, large waders are $(29.7 \%)$ and swimmers are $(29.0 \%)$.Divers $(5.8 \%)$ showed more abundance than small waders (5.6\%). They showed minor variations .Swimmers $(74.3 \%)$ showed high abundance than others in monsoon. The other minor groups are Divers $(15.1 \%)$ Small Waders $(9.3 \%)$ Large Waders in monsoon (1.3\%).Areal Foragers are absent in monsoon.In post monsoon Aerial Foragers (42.1\%) followed by Swimmers $\quad(28.1 \%)>$ large waders $\quad(16.5 \%)>$ divers $(7.3 \%)>$ Small waders $(6 \%)$. Seasonal mean abundance of waterfowls included in various ecological groups is shown in (Table 2).
Tables 2: Seasonal mean abundance of waterfowls included in various ecological groups

\begin{tabular}{|c|c|c|c|c|}
\hline \multirow{2}{*}{$\begin{array}{c}\text { Ecological } \\
\text { Group }\end{array}$} & Pre summer & summer & monsoon & $\begin{array}{c}\text { post } \\
\text { monsoon }\end{array}$ \\
\cline { 2 - 5 } & MEAN & MEAN & MEAN & MEAN \\
\hline Divers & $96.1 \pm 189.1$ & $8.9 \pm 15.6$ & $2.4 \pm 3.0$ & $12.65 \pm 18.5$ \\
\hline Swimmers & $155.3 \pm 276.2$ & $44.4 \pm 68.1$ & $11.6 \pm 23.0$ & $48.6 \pm 83.6$ \\
\hline Small Waders & $67.5 \pm 144.9$ & $8.6 \pm 16.9$ & $1.5 \pm 3.8$ & $10.3 \pm 21.1$ \\
\hline Large Waders & $116.7 \pm 242.3$ & $45.5 \pm 77.9$ & $0.2 \pm 0.4$ & $28.6 \pm 53.8$ \\
\hline Areal Foragers & $389.5 \pm 549.9$ & $45.8 \pm 64.8$ & $0.0 \pm 0.0$ & $72.9 \pm 103.1$ \\
\hline
\end{tabular}

\subsection{Seasonality}

Based on the statistical analysis all groups showed seasonal significant variation in abundance. (Table 11).Divers and Small waders, showed seasonality only in pre summer. At the same time Large Waders showed significance in abundance in all seasons. For large waders, the pre summer shows high significance in abundance than other seasons. Abundance of summer is more than the post monsoon and monsoon. Swimmers and Areal Foragers showed seasonality in pre summer, also between post monsoon and monsoon. More abundance is seen in pre summer than other seasons. The abundance of post monsoon is higher than the monsoon.

Tables 3: Result of anova and paired $t$ test on the variation of seasonal abundance of waterfowls included in various ecological groups

\begin{tabular}{|c|c|c|c|c|c|c|c|c|c|}
\hline \multirow{2}{*}{$\begin{array}{c}\text { Eco. } \\
\text { group }\end{array}$} & \multicolumn{4}{|c|}{ Anova } & \multicolumn{7}{|c|}{ Paired t test } \\
\cline { 2 - 12 } & $\mathrm{F}$ & $\mathrm{df}$ & $\mathrm{p}$ & PS-M & PS-S & PS-PM & PM-M & PM-S & S-M \\
\hline D & 45.89 & 3 & 0.000 & 0.000 & 0.000 & 0.000 & 0.271 & 0.686 & 0.48 \\
\hline SWM & 25.25 & 3 & 0.000 & 0.000 & 0.000 & 0.000 & 0.041 & 0.814 & 0.069 \\
\hline SWA & 123.36 & 3 & 0.000 & 0.000 & 0.000 & 0.000 & 0.028 & 0.653 & 0.075 \\
\hline LWA & 72.17 & 3 & 0.000 & 0.000 & 0.000 & 0.000 & 0.001 & 0.046 & 0.000 \\
\hline AF & 53.00 & 3 & 0.000 & 0.000 & 0.000 & 0.000 & 0.040 & 0.436 & 0.190 \\
\hline
\end{tabular}

$\mathrm{D}=$ Divers, $\mathrm{SWM}=$ Swimmers, $\mathrm{SWA}=$ Small Waders, $\mathrm{LWA}=$ Large Waders, $\mathrm{AF}=$ Areal Foragers

\section{Discussion}

\subsection{Abundance}

Different habitats of the Kole are utilized by birds of different ecological groups in different way in accordance with rain, temperature, water depth and climate conditions. Thus open deep water is suitable for both divers and swimmers, shallow water is for both large waders and aerial foragers and open mud flats are for small waders as well as large waders etc. Several studies have pointed out that water depth affects waterfowl diversity [2,3,4,13 \& 20]. .The number of species in each ecological group is varied; the small waders were the most dominant group with 18 species in the present study and aerial foragers are least group with two species. Among the 40 species of waterbirds belonging to five ecological groups recorded in Udhayamarthandapuram Bird Sanctuary; where large waders are the predominant group and divers are the less dominant group with 13 and 5 species respectively [23].

Of the five common divers reported in the Kole, the dominant diver is Microcarbo niger a resident bird which can be seen in all seasons. The least group is represented by
Phalacrocorax fuscicollis which is a locally migrant one and shift their place with respect to the seasonal changes in climatic conditions. Among swimmers the maximum abundance is shown by Dendrocygna javanica which is an active resident and the leading group in the waterfowl in the entire study period. The least swimmer Gallicrex cinerea $0.003 \%$ which is a rare bird.In the small wader group, Tringa glareola $(40.10 \%)$ holds the largest group which is a migrant seen as flocks in Kole during pre summer.The Vanellus cinerus (0.01) is the least abundant group which is also a migrant and a rare bird.Among the large waders Ardea intermedia $(37.77 \%)$ shows maximum abundance which is due to good habitat, climate and prey availability in the area.Platalea leucorodia shows minimum abundance which is a local migrant.

\subsection{Seasonal Abundance}

According to the present study Aerial Foragers are the dominant group in all seasons except monsoon. This is due to the returning of the migrant species Chlidonias hybrid before monsoon. Similarly small waders are found to be the least group in all seasons except monsoon which is also reported by AWC count of Kole wetland and earlier workers. The shore birds, an important group of wetland birds showed a

\section{Volume 4 Issue 12, December 2015}




\section{International Journal of Science and Research (IJSR) \\ ISSN (Online): 2319-7064}

Index Copernicus Value (2013): 6.14 | Impact Factor (2014): 5.611

decrease of $1.25 \%$ birds during 2011 and further a decrease of $0.56 \%$ birds during 2012 [22] .Presence of waders in this area may be due to the suitable habitat with sufficient food and shelter. Small waderse especially migrant shore birds were spread out gradually here during pre summer as their feeding zone. Similar remarks were made by earlier workers that the availability of mudflats is known to contribute to the high diversity of waders [14]. Vast extent of mudflats available at Kole wetlands was the prime habitat for waders [1].In Muriyad kole not only the waders but also the other waterfowls belonging to different ecological groups were made use of this area in pre summer for food.

\subsection{Seasonality}

Statistical analysis of all five groups showed seasonal significant variation in abundance. Both divers and small waders showed seasonality only in pre summer because most of the migrants were included in the small wader group while local migrants and residents were in the diver group. At the same time Large Waders showed significance in abundance in all seasons. The pre summer shows high significance in abundance than other seasons due to the arrival of migrant population. Their return coincidence with the onset of summer; so abundance of summer is more than the post monsoon and monsoon. Swimmers and Areal Foragers showed seasonality in pre summer, also between post monsoon and monsoon. More abundance is seen in pre summer than other seasons. The abundance of post monsoon is higher than the monsoon. This is because the high population of Areal Foragers Chlidonias hybrid and swimmer Dendrocygna javanica in the area.

\section{Conclusion}

Major threats of the Kole are habitat destruction, deforestation, sand and clay mining, hunting and poching, the indiscriminate use of pesticides and manures, wastes deposal, the uncontrolled growth of weeds and invasive species of plants, overgrazing and uncontrolled fishing practices. Any undesirable change in the Kole habitat will automatically affect the entire life of the Kole.So proper awareness should be given to all to safe guard the Kole life.As the Kole lands are located in the, ,Central Asian-Indian Fly Waye route of migratory birds both Government and every citizen should come forward to protect these wetlands and birds including the migrants.

\section{Acknowledgement}

One of the authors (Ajitha K.V) expresses her gratitude to the Kerala State Govt. for granting the E-grants Scholarship (Govt.of Kerala) to carry out the doctoral research.

\section{References}

[1] C. Sivaperuman, and E.A. Jayson, Structure and species composition of wetland birds in Kole Wetlands, Thrissur, Kerala.,Proceedings of the Thirteenth Kerala Congress2001, Thrissur, pp 152-157. 2001.
[2] C.R Isola, M.A Colwell, O.W Taft and R.J Safran Interspecific differences in habitat use of shorebirds and waterfowl foraging in managed wetlands of California's San Joaquin Valley. Waterbirds: 25(suppl. 2):196203,2002.

[3] C.R.Velasquez Managing artificial saltpans as a waterbird habitat: species responses to water level manipulation. Colonial Waterbirds 15:43-55. 1992.

[4] C.S Elphick and L.W Oring, Conservation implications of flooding rice fields on winter waterbird communities. Agriculture, Ecosystems and Environment 94:pp17-29, 2003.

[5] C.Sivaperuman and E.A. Jayson , Birds of Kole Wetlands ,Thrissur,Kerala., Zoos'print Journal 15(10): pp 344-349. 2000.

[6] C.Sivaperuman, and E.A. Jayson Occurance Northern Shoveller (Anas clypeate) Linnaeus in Kole Wetlands Thrissur Kerala. Journal of Bombay Natural History and Society 99 (3):pp 517. 2002.

[7] E.A.Jayson and C.Sivaperuman , Sighting of Lesser Frigate Bird Fregata ariel Gray in Kole Wetlands Thrissur Kerala. Journal of Bombay Natural History and Society 100 (1): pp 106-108. 2003.

[8] I. Johnkutty, and V.K Venugopal, Kolelands of Kerala. Kerala, Agricultural University.68 pages. 1993.

[9] J.,Praveen , R. Jayapal and A Pittie, Checklist of the birds of South Asia (Ver.1). 2014. Website: http://www.indianbirds.in/resources/.[Date of publication: 26 December 2014.]

[10] J.H. McDonald, "Handbook of Biological Statistics "Sparky House Publishing, Baltimore , 2008.

[11] J.T Emlen Estimating Breeding Season, Bird Densities from Transect counts. The Auk Vol 94:pp455-468,1977.

[12]K.John Thomas, S.Sreekumar. and Jaya Cheriyan Muriyad Wetlands: "Ecological Changes And Human Consequences" A Project report submitted to Kerala Research Programme on Local Development, Centre for Developmental Studies, Thiruvanandapuram. 2003.

[13] M.A. Colwell, and O.W. Taft, Water bird communites in managed wetlands of varying water depth. Water birds, 23: pp 1121-1133, 2000.

[14] M.W. Weller, Bird habitat relationship in Texas estuarine marsh during summer.Wetlands, 14 (4): 293300. 1994.

[15] M.Z Islam, and A.R. Rahmani Important Bird Areas in India. Priority sites for conservation. Indian Bird Conservation Network: Bombay Natural History Society, BirdLife International. Pp. xviii + 1133. 2004

[16] M.Z. Islam, and A.R. Rahmani , Potential and Existing Ramsar Sites in India. Indian Bird Conservation Network: Bombay Natural History Society, BirdLife International and Royal Society for the Protection of Birds. Oxford University Press. Pp 592. 2008.

[17] MoEF Integrated Development of Wildlife Habitats. Ministry of Environment \& Forests, New Delhi. Pp-83, 2009.

[18] R.E Stewart Jr. Technical aspects of wetlands: Wetlands bird habitat. United states Geological Survey water supply paper. pp $24-25.2007$.

[19]R.L Dean and J.H Connell. Marine invertebratesin an algal succession 1.Variation in abundance and diversity 
with succession..Journal of Experimental Marine Biology 109: pp 195-215. 1987.

[20] T. Darnell, E.H Smith, Avian use of natural and created salt marsh in Texas, USA. Waterbirds 27: pp 355-36, 2004.

[21]T.Jeena Srinivasan "Understanding the Kole Lands in Kerala asA Multiple Use Wetland Ecosystem" Working Paper No. 89 RULNR Working Paper No. 5 June, 2010.

[22] Tomy Francis and M. John George A glance into the avian fauna of kole wetlands of Thrissur Millennium Zoology VOL.14 (1), pp 36-41. 2013.

[23] V. Ramamurthy and R. Rajakumar A study of avifaunal diversity and influences of water quality in the Udhayamarthandapuram bird sanctuary, Tiruvarur District, Tamil Nadu, India , International Journal of Innovative Research in Science, Engineering and Technology Vol. 3, Issue 1, ISSN: 2319-8753 pp 88518858. 2014.

\section{Author Profile}

Ajitha K.V. PhD candidate in the PG and Research Department of Zoology, St. Joseph "es College, Devagiri, University of Calicut, Kerala, India. Research area is ORNITHOLOGY, study on the Kole Wetland Birds and Egrets of Muriyad, Thrissur District, Kerala, South India

Dr. Boby Jose, Associate Professor, PG and Research Department of Zoology, St. Joseph 's College, Devagiri, University of Calicut, Kerala, India. Research area is ORNITHOLOGY, $\mathrm{PhD}$ on the Ecological Isolation of Babblers (Turdoides spp.) 